\title{
A lectin histochemical study to detect variation in glycosylation at the feto-maternal interface in three interbreeding equine species
}

DOI:

10.1016/j.placenta.2017.08.075

\section{Document Version}

Accepted author manuscript

Link to publication record in Manchester Research Explorer

Citation for published version (APA):

Jones, C. J. P., Allen, W. R. T., \& Wilsher, S. (2017). A lectin histochemical study to detect variation in glycosylation at the feto-maternal interface in three interbreeding equine species. Placenta, 58, 115-121. https://doi.org/10.1016/j.placenta.2017.08.075

\section{Published in:}

Placenta

\section{Citing this paper}

Please note that where the full-text provided on Manchester Research Explorer is the Author Accepted Manuscript or Proof version this may differ from the final Published version. If citing, it is advised that you check and use the publisher's definitive version.

\section{General rights}

Copyright and moral rights for the publications made accessible in the Research Explorer are retained by the authors and/or other copyright owners and it is a condition of accessing publications that users recognise and abide by the legal requirements associated with these rights.

\section{Takedown policy}

If you believe that this document breaches copyright please refer to the University of Manchester's Takedown Procedures [http://man.ac.uk/04Y6Bo] or contact uml.scholarlycommunications@manchester.ac.uk providing relevant details, so we can investigate your claim.

\section{OPEN ACCESS}


Elsevier Editorial System(tm) for Placenta Manuscript Draft

Manuscript Number: PL-17-00069R2

Title: A Lectin Histochemical study to Detect Variation in Glycosylation at the Feto-maternal Interface in Three Interbreeding Equine Species

Article Type: Full Length Article

Keywords: placenta; equine; zebra; glycans; lectin histochemistry

Corresponding Author: Dr. Carolyn Jane Jones, PhD, DMedSc

Corresponding Author's Institution: University of Manchester

First Author: Carolyn Jane Jones, PhD, DMedSc

Order of Authors: Carolyn Jane Jones, PhD, DMedSc; William (Twink) R Allen, PhD; Sandra Wilsher, $\mathrm{PhD}$

Abstract: Introduction: In this study, we compare glycosylation at the feto-maternal interface in 3 equine species: horse, donkey and zebra, all of which can interbreed to produce hybrids, to assess their glycan similarities and differences.

Methods: Sections cut from 3 specimens of horse (Equus caballus) placenta (50, 200 and 280 days gestation), one donkey (Equus asinus) placenta ( $65 \mathrm{~cm}$ crown-rump length) and 5 specimens of zebra (Equus quagga) placentae (81 to 239 days gestation) were stained with a panel of 24 biotinylated lectins using an avidin-peroxidase revealing system. Results: There were only slight quantitative differences in the lectin histochemistry at the feto-maternal interface between all three specimens; zebra placentae expressed more $\alpha 2,6$-linked sialic acid, with $\alpha 1,2$ fucosyl residues at the microvillous interface. However, zebra trophoblast showed histological differences from the other two species, with polarised cells, prominent supranuclear Golgi bodies, and fewer intracellular granules.

Discussion: Our findings appear to confirm the hypothesis that closely related, interbreeding species with epitheliochorial placentae express similar glycans at the feto-maternal interface, thereby supporting the existence of a placental glycocode. We also observed intraspecies evolutionary diversion to be associated with a different histological architecture and the absence of significant intracellular granules. 
Response to Reviewers

Reviewer \#1: I do not think that the first sentence in the abstract is justified.It should be removed. All of the important results of the glycoconjugate comparisons have been carried out on mid to late gestation material. They form an important and scientifically useful comparison of species differences and similarities. They measure the expression at the microvillar junction, trophoblast and uterine epithelium together. Noonehas shown the expression of glycoconjugates on the separate maternal and embryonic surfaces at implantation to validate or otherwise the "glycocode" hypothesis. The rest of the paper is now modified suitably.

As suggested by this reviewer, we have removed the first sentence and modified the text appropriately: "In this study, we compare glycosylation at the fetomaternal interface in 3 equine species: horse, donkey and zebra, all of which can interbreed to produce hybrids, to assess their glycan similarities and differences."

Reviewer \#3: There is an adequate response to the points raised by Reviewer \#1 and a rebuttal of the concerns raised by Reviewer \#2. I share some of this reviewer's reservations, which arise directly from the interpretation of the lectin histochemistry being dependent a single author.

Two additional points that must be dealt with before publication:

1) The Figure legends should define the abbreviations used in the figures, e.g. MVM. This has been addressed, with addition of more labels in Figure 2.

2) The authors are selective in mentioning only embryo transfer from the bovine to sheep or goats, which are classified in separate subfamilies (Bovinae and Antilopinae) by Groves and Grubb and other experts. They ought also to cite the cross between Gaur (Bos frontalis) and domestic cattle (Bos taurus) that proceeds far past the stage of blastocyst elongation albeit with defects in placentation (Hradecký Theriogenology 1988; 30: 593-604). This is far more relevant to the current study of three species of the genus Equus.

The authors thank this reviewer for pointing out this important reference and a new sentence has been added (lines 191 - 6): "However, embryo transfer between a gaur (Bos gaurus) and domestic Holstein (Bos taurus), which have similar gestational lengths, was partially successful [18] with three pregnancies resulting from four embryo transfers. Examination of the placenta of one of these, a dead 9.5 month gaur calf, of small size and with poor muscle development, showed inadequate branching of the chorionic villi and poor penetration into the spaces available in the maternal crypts [19], indicative of a placentation problem in the heifer."

We hope the paper is now acceptable for publication in Placenta. 
August $23^{\text {rd }} 2017$

Dear Martin,

Once again I have pleasure in sending you a newly revised version of our manuscript "A Lectin Histochemical Study to Detect Variation in Glycosylation at the Feto-maternal Interface in Three Interbreeding Equine Species" in which we have addressed the comments of the reviewers. I trust it is now acceptable for publication in Placenta. Both my co-authors have approved these changes.

I am keeping very well, thank you, though I have another dose of chemotherapy two days before the meeting. I tried to get it changed but was told it was not in my best interest to do so, so I am hoping I will be fit enough to attend.

All being well, I look forward to meeting you in a few days' time!

Kind regards,

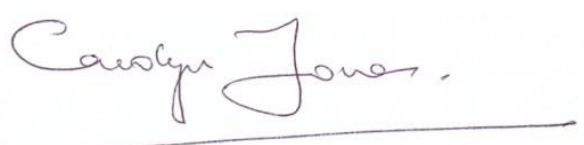

Carolyn Jones, PhD, D.Med.Sc

(Honorary Research Fellow) 


\section{Conflict of Interest Declaration}

We wish to confirm that there are no known conflicts of interest associated with thispublication and there has been no significant financial support for this work that could haveinfluenced its outcome.

We confirm that the manuscript has been read and approved by all named authors and thatthere are no other persons who satisfied the criteria for authorship but are not listed. Wefurther confirm that the order of authors listed in the manuscript has been approved by allof us.

We confirm that we have given due consideration to the protection of intellectual propertyassociated with this work and that there are no impediments to publication, including thetiming of publication, with respect to intellectual property. In so doing we confirm that wehave followed the regulations of our institutions concerning intellectual property.

No aspect of the work covered in this manuscript has involved human patients.

We understand that the Corresponding Author is the sole contact for the Editorial process(including Editorial Manager and direct communications with the office). She is responsiblefor communicating with the other authors about progress, submissions of revisions and finalapproval of proofs. A current, correct email address has been provided on the title page ofthe manuscript.

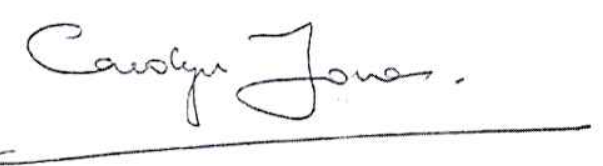

Carolyn J.P. Jones

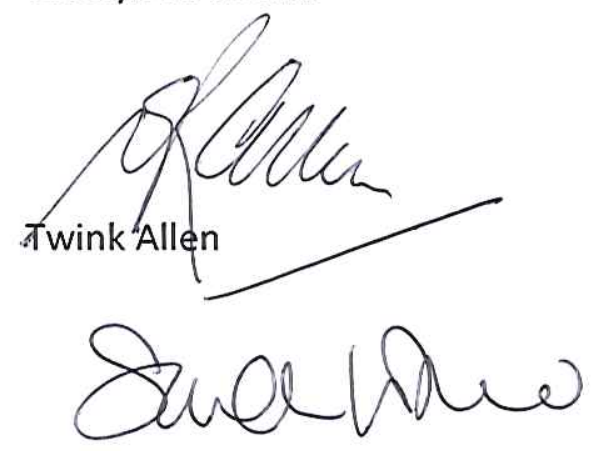

Sandra Wilsher 
A Lectin Histochemical Study to Detect Variation in Glycosylation at the Feto-maternal

\title{
Interface in Three Interbreeding Equine Species
}

\author{
Carolyn J.P. Jones ${ }^{1^{*}}$ \\ W.R. (Twink) Allen ${ }^{2}$ \\ Sandra Wilsher ${ }^{2}$
}

${ }^{1}$ Maternal and Fetal Health Research Centre, Division of Developmental Biology and Medicine, School of Medical Sciences, Faculty of Biology, Medicine and Health, The University of Manchester, Oxford Road, Manchester, M13 9WL, ${ }^{2}$ The Paul Mellon Laboratory, 'Brunswick', 18 Woodditton Road, Newmarket, Suffolk CB8 9BJ, UK.

*Author for correspondence:

Carolyn J.P. Jones, PhD., DMedSc,

5th floor (Research), St Mary's Hospital, Oxford Road, Manchester M13 9WL, UK

Email: carolyn.jones@manchester.ac.uk Tel: 44 (0) 1612766916 


\begin{abstract}
Introduction: In this study, we compare glycosylation at the feto-maternal interface in 3 equine species: horse, donkey and zebra, all of which can interbreed to produce hybrids, to assess their glycan similarities and differences.
\end{abstract}

Methods: Sections cut from 3 specimens of horse (Equus caballus) placenta (50, 200 and 280 days gestation), one donkey (Equus asinus) placenta ( $65 \mathrm{~cm}$ crown-rump length) and 5 specimens of zebra (Equus quagga) placentae ( 81 to 239 days gestation) were stained with a panel of 24 biotinylated lectins using an avidin-peroxidase revealing system.

Results: There were only slight quantitative differences in the lectin histochemistry at the feto-maternal interface between all three specimens; zebra placentae expressed more $\alpha 2,6$ linked sialic acid, with $\alpha 1,2$ fucosyl residues at the microvillous interface. However, zebra trophoblast showed histological differences from the other two species, with polarised cells, prominent supranuclear Golgi bodies, and fewer intracellular granules.

Discussion: Our findings appear to confirm the hypothesis that closely related, interbreeding species with epitheliochorial placentae express similar glycans at the fetomaternal interface, thereby supporting the existence of a placental glycocode. We also observed intraspecies evolutionary diversion to be associated with a different histological architecture and the absence of significant intracellular granules. 
Highlights

- Glycans at the horse, donkey and zebra placental interface shows many similarities

- Zebra trophoblast shows histological polarisation lacking in horse and donkey

- Zebra trophoblast shows a vesicular structure with few intracellular granules

- Despite structural changes placental glycans are similar in zebra, horse and donkey

- Interbreeding Equid species share a placental glycocode 
1 A Lectin Histochemical Study to Detect Variation in Glycosylation at the Feto-maternal

2

3

4

5

$6 \quad{ }^{1}$ Maternal and Fetal Health Research Centre, Division of Developmental Biology and

7 Medicine, School of Medical Sciences, Faculty of Biology, Medicine and Health, The

8 University of Manchester, Oxford Road, Manchester, M13 9WL, ${ }^{2}$ The Paul Mellon

9 Laboratory, 'Brunswick', 18 Woodditton Road, Newmarket, Suffolk CB8 9BJ, UK.

$11 *$ *Author for correspondence:

12 Carolyn J.P. Jones, PhD., DMedSc,

13 5th floor (Research), St Mary's Hospital, Oxford Road, Manchester M13 9WL, UK

14 Email: carolyn.jones@manchester.ac.uk Tel: 44 (0) 1612766916

15 
Introduction: In this study, we compare glycosylation at the fetomaternal interface in 3 equine species: horse, donkey and zebra, all of which can interbreed to produce hybrids, to assess their glycan similarities and differences.

Methods: Sections cut from 3 specimens of horse (Equus caballus) placenta (50, 200 and 280 days gestation), one donkey (Equus asinus) placenta ( $65 \mathrm{~cm}$ crown-rump length) and 5 specimens of zebra (Equus quagga) placentae (81 to 239 days gestation) were stained with a panel of 24 biotinylated lectins using an avidin-peroxidase revealing system.

Results: There were only slight quantitative differences in the lectin histochemistry at the feto-maternal interface between all three specimens; zebra placentae expressed more $\alpha 2,6$ linked sialic acid, with $\alpha 1,2$ fucosyl residues at the microvillous interface. However, zebra trophoblast showed histological differences from the other two species, with polarised cells, prominent supranuclear Golgi bodies, and fewer intracellular granules.

Discussion: Our findings appear to confirm the hypothesis that closely related, interbreeding species with epitheliochorial placentae express similar glycans at the fetomaternal interface, thereby supporting the existence of a placental glycocode. We also observed intraspecies evolutionary diversion to be associated with a different histological architecture and the absence of significant intracellular granules. 


\section{Introduction}

We have previously examined glycosylation of the feto-maternal interface in the horse (Equus caballus) and donkey (Equus asinus), which can interbreed [1], and found a general similarity of glycan expression in the two species [2]. This is in contrast to the situation in the Old World dromedary camel (Camelus dromedarius) and the New World camelids which cannot freely interbreed and show a different glycosylation pattern at their placental interface [2]. The opportunity to examine placentae of the Common or Plains zebra (Equus quagga, formerly Equus burchelli), allowed comparison of zebra placental glycosylation with that of the horse and donkey, all three of which can interbreed $[2,3]$. It also enabled us to test our previous postulate $[4,5]$ that glycosylation at the feto-maternal interface is regulated by a glycocode which prevents attachment and interdigitation of the trophoblast with an inappropriate maternal epithelium and, hence, hybridisation or extragenetic embryo transfer.

\section{Materials and methods}

\subsection{Animals}

As described previously [6], the gravid uteri of 5 adult female Common or Plains zebra ranging in estimated gestational age from 81 to 239 days (see Table 1), and culled for management reasons in Zimbabwe, were dissected $90-120$ min after death and pieces of the placental interface were fixed in $10 \%$ neutral buffered formalin (NBF). The fixed tissues were transported to the UK where they were post-fixed in $2.5 \%$ glutaraldehyde in $0.1 \mathrm{M}$ sodium cacodylate buffer $\mathrm{pH} 7.4$ for $3 \mathrm{~h}$ at room temperature. After washing 3 times over 
$24 \mathrm{~h}$ in $0.1 \mathrm{M}$ sodium cacodylate buffer containing $1 \mathrm{mM} \mathrm{CaCl}_{2}$, the tissues were trimmed and embedded in epoxy resin for lectin histochemistry.

Three resin-embedded specimens of horse placenta at 50, 200 and 280 days gestation (term = 329-342 days) were obtained courtesy of Dr Peter Wooding (University of Cambridge, UK). The 50 day specimen had been immersion-fixed in $4 \%(\mathrm{v} / \mathrm{v})$ glutaraldehyde; the placenta at 200 days was fixed by immersion in $3 \%(\mathrm{w} / \mathrm{v})$ paraformaldehyde with $1 \%(\mathrm{v} / \mathrm{v})$ glutaraldehyde and the $\mathbf{2 8 0}$ day placenta was perfused from both maternal and fetal sides with the same fixative.

One specimen of donkey placenta from a fetus of $65 \mathrm{~cm}$ crown-rump length (see Table 1 ), kindly provided by V. Dantzer (Royal Veterinary and Agricultural University, Denmark) was also used in this study. It had been perfusion-fixed with $3 \%(\mathrm{v} / \mathrm{v})$ glutaraldehyde in $0.1 \mathrm{M}$ phosphate buffer, $\mathrm{pH} 7.3$, with added $2 \%(\mathrm{w} / \mathrm{v})$ polyvinylpyrrolidone via a small branch of the uterine artery on the maternal side and a branch of the umbilical artery on the fetal side. After immersion fixation for a further two hours it was processed into epoxy resin.

\subsection{Lectin histochemistry.}

Semithin sections $(0.75 \mu \mathrm{m})$ were cut on a Reichert OMUIII ultramicrotome and mounted on APES-coated slides. Resin was removed using saturated sodium ethoxide diluted $1: 1$ with absolute ethanol, after which the sections were stained with a carefully selected panel of 24 biotinylated lectins as described previously [7], followed by an avidin-peroxidase revealing system; some were treated with Type VI neuraminidase (Sigma, from Clostridium perfringens) in $0.2 \mathrm{M}$ acetate buffer, $\mathrm{pH} 5.5$, with $1 \%(\mathrm{w} / \mathrm{v})$ calcium chloride at $37^{\circ} \mathrm{C}$ for $2 \mathrm{~h}[8]$ to cleave off terminal sialic acid. Controls were as described previously. All the specimens 
were stained together with selected lectins to avoid any day-to-day variation and to enable between-species comparisons to be made with confidence. See Table 2 for lectin binding specificities and their sources.

Sections were assessed using a ranking system of analysis whereby staining intensity was graded from 0 (negative) to 4 (intensely stained) and intracellular granule density was graded from + (sparse) to +++ (densely packed). With the zebra trophoblast and endometrial epithelium, the amount of staining around vesicular structures was similarly assessed and graded.

\section{Results:}

\subsection{General histology}

After apposition and attachment, the trophoblast and maternal uterine epithelium interdigitate with each other via their surface microvilli to form an undulating placental membrane which folds so that trophoblast villi are accommodated within maternal endometrial crypts. Surprisingly, the trophoblast of the Zebra placenta differed from that of the horse and donkey in that the trophoblast lacked the presence of large, irregular granules described previously in later gestation in the horse [9] and tended to be more polarised, with cuboidal cells bearing long microvilli and sub-microvillous granules that were visible when staining with some lectins. Supranuclear Golgi bodies were often detected and the cytoplasm appeared to be composed of a sponge-like substructure with hollow vesicles and occasional solid granules. Due to the inevitable delay in obtaining tissue from culled animals, the fixation was often suboptimal, especially in the early gestation specimens 
where the trophoblast had retracted away from the maternal epithelium and the villous core was sometimes lost completely.

The maternal uterine epithelium was generally more flattened and it contained some granules; darkly staining structures adjacent to the nuclei were observed occasionally which may have been Golgi bodies. The microvilli of these maternal epithelial cells were much shorter than those of the trophoblast. The horse and donkey placentae were similar in appearance to one another and in both species the granules in the trophoblast cells seemed randomly dispersed and lacked the polarity seen in the zebra. Some large inclusions were also present, as has been described previously $[9,10]$. Figure 1 shows typical fields of the placental barrier of horse, donkey and zebra stained with WFA to show the general characteristics.

\subsection{Lectin Histochemistry}

In general, there was little change in glycan expression over the period of gestation studied. In many cases the uterine epithelium showed apical microvillous staining when the cytoplasm was unstained, suggesting the possibility that this had resulted from trophoblast microvillous glycan adhering to the epithelium, rather than being synthesised by it.

\subsubsection{Trophoblast_(see Table 3)}

Trophoblast bound several lectins strongly, especially at the earliest stage examined (day 81). The cytosol had a vesiculated appearance (Fig. 2A) and component granules were not easily detectable, even though the vesicular structures bound many lectins more strongly than the background cytosol. The apical membrane, which was clothed in microvilli that were longer than those on the uterine epithelium, was stained intensely by all the lectins 
used in the study apart from MAA, though it is possible that with UEA-1 some of the staining was to uterine glycan adhering to microvilli upon post-mortem loosening of the interdigitation (Fig. 2B). The cytosol varied from virtually unstained (MAA), to very pale (IPHA, UEA-1, DBA, VVA, SBA), to more strongly stained as with most other lectins, and invariably the intensity of stain increased considerably just under the microvillous surface. In the later stages of gestation, populations of small, discrete granules could only be detected with certainty when using PSA, ALA (Fig. 2C), GNA and LEA, particularly in the apical regions of the cell, and supranuclear foci of staining, probably Golgi bodies judging by their shape and location, were particularly prominent with $\mathrm{ALA}, \mathrm{BSA}-1 \mathrm{~B}_{4}, \mathrm{PAA}$ and WGA staining, the latter two both with and without neuraminidase pretreatment (Fig. 2D). This feature was most prominent at the later stages of gestation studied. Cell membranes were stained particularly strongly, especially at the apical tips of the microvilli, with ePHA, MPA (Fig. 2E), DSA, STA, HPA, AHA and ECA (+/-N), WFA, SNA-1 and PAA (+/-N).

\subsubsection{Maternal uterine epithelium (see Table 4)}

These cells were generally shallower than the trophoblast, and became flatter over the course of gestation. The microvilli were short but they stained strongly with almost all the lectins apart from IPHA and MAA. Occasional paranuclear areas which stained more strongly, and which may have been Golgi bodies, were seen with ePHA, UEA-1, ALA, DBA, VVA, WFA, PAA and WGA (these last two both with and without neuraminidase pretreatment) (Figs $2 \mathrm{~A}, \mathrm{~B}$. C). Cytosol bound most lectins, apart from IPHA, BSA-1B ${ }_{4}$ and MAA, though most tailed off in intensity as gestation advanced. With some lectins (ePHA, PSA and SNA-1), occasional deeply stained cells were seen which may have represented a degree of degeneration as reported in a previous study [11]. Lateral cell membranes were 
strongly stained with UEA-1 (Fig. 2B), DBA, DSA, STA, AHA (+/-N), ECA (+/-N) and WFA (Fig. 1 H). The large granules seen in horse and donkey epithelia were absent in Zebra tissues, and GNA staining, indicative of lysosomes, was generally confined to the underside of the microvillous membrane, where it was less intense than the equivalent staining in trophoblast (Fig. 2F).

Neuraminidase pretreatment had little effect on lectin staining of both trophoblast and maternal epithelium, though stromal components (vessels and connective tissue) showed stronger staining with AHA and ECA in all three species.

Examination of Tables 3 and 4 shows that differences between horse and donkey placental glycosylation were not particularly marked and they were more quantitative than qualitative in nature, with the general patterns of binding being similar in both species. Staining of donkey trophoblast with IPHA and ALA tended to be more intense, while the uterine epithelium showed only minimal differences.

In general, the lectin binding characteristics of zebra placenta were not dissimilar to that of horse and donkey, despite the absence of detectable intracellular granules. There was more evidence of binding with SNA-1 in both trophoblast and uterine epithelial cytoplasm, and one feature of the zebra that was absent in horse and donkey was staining of the microvilli with LTA (Fig. $2 \mathrm{G}, \mathrm{H}$ ); this was more apparent on the long trophoblast microvilli, though uterine microvilli were also bound with the lectin. The trophoblast and uterine epithelial cytoplasm were also weakly stained with LTA, more so than in the horse and donkey. With UEA-1, there was heavy binding by the uterine epithelium in all three species but in the zebra, in areas where the trophoblast and epithelium had separated, there was often patchy staining of the trophoblast microvillous surface (Fig. 2E); it was not possible to say whether 
this originated from interdigitation with the uterine epithelium or was produced

endogenously, but its superficial nature and lack of cytoplasmic stain suggested the former.

There was more binding of DBA and VVA to granules in the trophoblast in horse and donkey although some diffuse binding was present in zebra (Fig. $2 \mathrm{I}, \mathrm{J}$ ).

\section{Discussion:}

We have shown previously that genetically related and interbreeding species with an epitheliochorial placenta usually express similar glycans at the feto-maternal interface [2]. Both the maternal and fetal interdigitating surfaces are highly glycosylated and each has its own particular pattern of glycosylation, or glycotype. The glycans on the apposing surfaces are required to be compatible for successful implantation, suggesting the existence of a "glycocode" in each species which may act to prevent interspecies hybridisation [12] and extragenetic embryo transfer. It has been shown, in experiments to produce hybrids between sheep and goat $[13,14]$ or species of mouse $[15,16]$, that to prevent rejection the implanting blastocysts needed to be manipulated to produce a chimaera in which the outer trophectoderm cells come from the same species as the recipient. We confirmed this when examining the placenta of a Cama (camel-Ilama hybrid), in which placental glycosylation resembled that of the maternal (Ilama) rather than the paternal (camel) species [12]. Furthermore, although bovine embryos can be temporarily transferred to sheep or goat uteri and continue development, albeit at a slower rate than in an homologous recipient, this has only been demonstrated to the point of blastocyst elongation [17], not implantation. However, embryo transfer between a gaur (Bos gaurus) and domestic Holstein (Bos taurus), which have similar gestational lengths, was partially successful [18] 
one of these, a dead 9.5 month gaur calf, of small size and with poor muscle development,

showed inadequate branching of the chorionic villi and poor penetration into the spaces available in the maternal crypts [19], indicative of a placentation problem in the heifer. It was therefore of interest to examine glycosylation at the fetomaternal interface in specimens of the Common zebra (Equus quagga) in comparison with other Equus species. Horses $(2 n=64)$, donkeys $(2 n=62)$ and zebras $(2 n=44)$ all have different karyotypes and their hybrids exhibit a karyotype that is intermediate between those of the two parental species [1] and which results in infertility. However, the fact that such hybrids can exist implies compatibility between the glycocodes of the trophoblast and maternal epithelium in all three species.

This has been confirmed in the present study, with very little qualitative differences in the expression of the various classes of glycan at the feto-maternal interface in all three species. Previous work from our laboratory on Camelus dromedarius, a species that does not interbreed with equids $[2,12,17]$, shows that the latter have more trophoblastic bi/triantennary bisected and non-bisected N-glycan (ePHA, I-PHA, PSA), less $\alpha 1,2$-linked fucose (LTA) and more $\mathrm{N}$-acetyl glucosamine oliogomers bound by DSA and LEA . Fucose bound by UEA-1, however, was more evident in the camel, as was terminal $\mathrm{N}$-acetyl galactosamine bound by SBA. There was also a complete absence of GalNAc $\alpha 1,3-$ (LFuca1,2)Galß1,3/4GIcNAcß1 bound by DBA in the camel and $\mathrm{N}$-acetyl glucosamine oligomers (PAA) were also more sparsely expressed. The uterine epithelium in the camel also showed differences, with no binding of DBA to GalNAca1,3(LFuc $\alpha 1,2)$ Galß1,3/4GlcNAcß1, and lower levels of complex N-glycan bound by PSA, ePHA, IPHA but more $\alpha 1,2-$ linked fucosyl residues (LTA) though, in the camel, more changes were observed with the 
progression of pregnancy [20] than in the zebra where glycosylation remained relatively uniform.

The main difference between the zebra and other equids was found to be the presence of more $\alpha 2,6$-linked sialic acid (shown by SNA-1) in both the trophoblast and the maternal epithelium, and $\alpha 1,2$-linked fucosyl residues (LTA) at the microvillous interface in the zebra, which was not evident in the other two species. Fucose in $\alpha 1,6$-linkage, bound by ALA, is generally distributed ubiquitously in the specimens we have examined, in contrast to that in a1,2-linkage which is always much more selectively expressed and which appears to be important in separating out different glycotypes [21]. It was surprising, therefore, that the most diversity occurred in the histology of the zebra trophoblast; the degree of polarisation seen there was not evident in either of the other two species, best exemplified by the regular disposition of the purported Golgi bodies as shown particularly well after WGA and PAA staining. The classical ultrastructural studies of equine placenta by Bjorkman and Samuel et al. $[9,22,23]$ do not mention the location of Golgi bodies in the trophoblast, though small cisternae may be observed in the paper by Samuel et al. [23] lying lateral to the nucleus in a 61 day specimen. Likewise, there was an absence in the zebra of the large, irregular granules seen in horse and donkey trophoblast and described at the ultrastructural level by Samuel et al. [9], which may be lysosomal in nature. A study of the zebra placenta by Kayanja [24] did not report the presence of Golgi bodies in the trophoblast; some small supranuclear dilated vacuoles could be observed in one figure but with poor resolution but significant lysosomal structures were not seen. Even at the earliest stage examined, the cytoplasm of zebra trophoblast was trabecular/vesicular in structure but it exhibited few detectable granules apart from those seen with GNA which binds to lysosomes [25]. The 
reason for this diversity between zebra trophoblast cellular organisation and that of horse and donkey is not clear but may relate to the packaging and disposal of waste products via lysosomes, those in the zebra being extruded via the apical membrane while remaining intracellular as secondary lysosomes in the other two species. The extrusion process in the zebra trophoblast may have led to the development of more polarisation while, in the horse and donkey, the secondary lysosomes were seen to be lying in random positions within the cell.

As with horse and donkey, most classes of glycan were present on zebra trophoblast apart from $\alpha 2,3$-linked sialic acid (MAA) and GaINAca1,3 residues (DBA and VVA). Terminal GalNAc $\alpha 1$ and tri/tetra-antennary, non- bisected complex N-linked sequences (IPHA) were present but were only weakly expressed. N-acetyl glucosamine residues appeared to be concentrated in the supranuclear Golgi bodies as shown by PAA, WGA, LEA, as was Gal $\alpha 1,3$ Galß1,4GIcNAcß1- bound by BSA-1B4 in later pregnancy, and some $\alpha 1,6$-linked fucosyl residues (ALA binding). All these were also evident on the microvillous membranes. The uterine epithelium also showed secretory properties, with a glycosylated microvillous membrane and active Golgi bodies which expressed bi-triantennary bisected complex Nglycan (ePHA), $\mathrm{N}$-acetyl galactosamine (DBA, VVA, WFA) as well as $\mathrm{N}$-acetyl glucosamine residues (PAA, WGA) and fucose in $\alpha 1,2$ and $\alpha 1,6$ linkage (UEA-1, ALA); other residues were evident but less prominent. In horse and donkey, Golgi bodies could not be distinguished from other glycosylated structures.

In summary, our findings confirm the hypothesis put forward in earlier publications that closely related and/or interbreeding species share similar glycosylation patterns at the fetomaternal interface. However, this is the first case in which we have observed intraspecies 
evolutionary diversion to be associated with the development of a different histological

264 architecture and intracellular granule formation.

\section{Funding}

This research did not receive any specific grant from funding agencies in the public, commercial, or not-for-profit sectors.

\section{References}

[1] R.V. Short, Species Differences, in: C.R. Austin, R.V. Short RV (Eds), Reproduction in

[2] C.J.P. Jones, F.B.P. Wooding, M.M. Abd-Elnaiem, R. Leiser, V. Dantzer, R.W. Stoddart, (2000) Glycosylation in the near-term epitheliochorial placenta of the horse, donkey and camel: a comparative study of interbreeding and non-interbreeding species. J. Reprod. Fertil. 118 (2000) 397-405.

[3] A.P. Gray, Mammalian Hybrids. Commonwealth Agricultural Bureaux, Farnham Royal, Slough, 1972.

[4] C.J.P. Jones, J.D. Aplin, Glycosylation at the fetomaternal interface: does the glycocode play a critical role in implantation? Glycoconj. J. 26 (2009) 359-366. 
[6] W.R. Allen, F. Stansfield, S. Wilsher, Placentation in the plains zebra (Equus quagga).

284

285

286

287

288

289

290

291

292

293

294

295

296

297

298

299

300

301

302

303

Reprod. Fertil. Dev. 2017 Mar 30. doi: 10.1071/RD16475. [Epub ahead of print]

[7] C.J.P.Jones, A.M. Carter, A.C. Enders, Glycosylation at the fetomaternal interface in haemomonochorial placentae from five widely separated species of mammal: is there evidence for convergent evolution? Cells Tiss. Org. 185 (2007) 269-284.

[8] C.J. Jones, C.A. Morrison, R.W. Stoddart, Histochemical analysis of rat testicular glycoconjugates. 2. Beta-galactosyl residues in $\mathrm{O}$ - and $\mathrm{N}$-linked glycans in seminiferous tubules. Histochem. J. 24 (1992) 327-336.

[9] C.A. Samuel, W.R. Allen, D.H. Steven, Studies on the equine placenta II. Ultrastructure of the placental barrier. J. Reprod. Fert. 48 (1976) 257-264.

[10] C.J.P. Jones, F.B.P. Wooding, V. Dantzer, R. Leiser, R.W. Stoddart, A lectin binding analysis of glycosylation patterns during development of the equine placenta. Placenta 20 (1999) 45-57.

[11] C.J.P. Jones, B-M. Bäcklin, R.W. Stoddart, V. Dantzer, Environmental pollutants as aetiological agents in female reproductive pathology: placental glycan expression in normal and polychlorinated biphenyl (PCB)-exposed mink (Mustela vison). Placenta 18 (1997) 689699.

[12] C.J.P. Jones, J.A. Skidmore, J.D. Aplin, Placental glycosylation in a Cama (Camel-Llama Cross) and its relevance to successful hybridisation. Mol. Phyl. Evol. 49 (2008) 1030-1035.

[13] C.B. Fehilly, S.M. Willadsen, E.M. Tucker, Interspecific chimaerism between sheep and goat. Nature (Lond) 307 (1984) 634-636. 
304

305

306

307

308

309

310

311

312

313

314

315

316

317

318

319

320

321

322

323

[14] S. Meinecke-Tillmann, B. Meinecke, Experimental chimaeras-removal of reproductive barrier between sheep and goats. Nature (Lond). 307 (1984) 637-638.

[15] J. Rossant, W.I. Frels, Interspecific chimeras in mammals: successful production of live chimeras between Mus musculus and Mus caroli. Science 208 (1980) 419-421.

[16] J. Rossant, B.A. Croy, D.A. Clark, V.M. Chapman, Interspecific hybrids and chimeras in mice. J. Exp. Zool. 228 (1983) 223-233.

[17] C.J.P. Jones, M. Abd-EInaeim, E. Bevilacqua, L.V. Oliveira, R. Leiser, Comparison of utero-placental glycosylation in the camel (Camelus dromedarius) and alpaca (Lama pacos). Reproduction 123 (2002) 115-126.

[18] J. Stover, J. Evans, E.P. Dolensek, Interspecies embryo transfer from the gaur to domestic Holstein. Proc. Annual AAZV Meeting, Seattle (1981) 122-124.

[19] P. Hradecký, J. Stover, G.G. Stott, Histology of a heifer placentome after interspecies transfer of a gaur embryo. Theriogenology 30 (1988) 593-604.

[20] L. Rodríguez-Alvarez, J. Cox, F. Navarrete, C. Valdés, T. Zamorano, R. Einspanier, F.O. Castro, Elongation and gene expression in bovine cloned embryos transferred to temporary recipients. Zygote 17 (2009) 353-365.

[21] J.D. Aplin, C.J.P. Jones, Fucose, placental evolution and the glycocode. Glycobiol 22 (2012) 470-478.

[22] N. Bjorkman, The fine morphology of the area of foetal- maternal apposition in the equine placenta. Z. Zellforsch. 65 (1965) 285-289. 

of the microcotyledons. J. Reprod. Fert. 41 (1974) 441-445.

[24] F.I.B. Kayanja, The fine structure of the placenta of the zebra Equus burchellii, Gray. Afr. changes in rat liver? Mech. Ageing. Dev. 102 (1998) 33-43.

[26] O.J. Ginther, Reproductive Biology of the Mare. Basic and Applied Aspects. $2^{\text {nd }}$ Ed. Equiservices, Cross Plains, Wisconsin 53528, 1992, p. 396.

\section{Legends to figures}

Figure 1: Semithin sections of horse (A-C,) donkey (D) and zebra (E-H) stained with WFA to show general structure.

A) 50 day horse placenta showing simple apposition of the trophoblast $(T)$ to the maternal uterine epithelium (ME). There are numerous pleomorphic granules in the trophoblast while a flatter maternal epithelium contains few granules. MVM: microvillous membrane.

B) At 200 days, villi of the microcotyledons contain many small granules, mainly under the

340 microvillous membrane, while in the maternal epithelium the inclusions are less well 341 defined.

C) By 280 days, the appearance has not really changed. but the staining characteristics are similar to those of the horse. 
E) At 81 days, the zebra trophoblast binds WFA strongly, especially on the microvillous surface, and the vesicular, rather than granular, nature of the cytoplasm can be observed.

F) The 81 day zebra maternal epithelium is darkly stained, especially apically, and a uterine gland can be seen. The trophoblast (E) and maternal epithelium (F) have separated from each other.

G) At 195 days, the intensity of WFA binding in zebra placenta has decreased in both trophoblast and maternal epithelium, apart from the microvillous membranes. The vesicular nature of the trophoblast, and its lack of intracellular granules, is apparent.

H) By 239 days the staining has decreased slightly but there is otherwise little change. T: trophoblast, ME: maternal epithelium, MVM: microvillous membrane. Scale bars: $25 \mu \mathrm{m}$

\section{Figure 2: Characteristics of the zebra placenta.}

A) The vesicular nature (arrows) of the trophoblast ( $T$ ) can be appreciated after staining this 195 day placenta with ePHA. Paranuclear structures in the maternal epithelium may be Golgi bodies (G).

B) In this 230 day zebra placenta, possible Golgi bodies (G) can again be seen in the maternal epithelium (ME) with UEA-1 staining. Where the trophoblast (T) has retracted from the maternal epithelium, it has a deeply stained microvillous surface (arrowheads), although this may not be endogenous. 
C) With ALA at 230 days, dark staining granules are evident in the trophoblast (T), especially under the microvillous membrane, while possible Golgi bodies $(G)$ are again visible in the maternal epithelium (ME).

D) Regularly spaced, supranuclear structures that are probably Golgi bodies (G) can be seen in the trophoblast of this 195 day placenta after WGA staining with neuraminidase pretreatment.

E) Strong staining of lateral cell membranes can be seen in this 239 day placenta stained with MPA.

F) The distribution of lysosomes can be seen after GNA staining of the 195 day placenta; in

373 the maternal epithelium (ME) they are mainly subapical while they are more generally

374 dispersed in the trophoblast $(T)$. Some of the latter appear to be hollow. MVM: microvillous membrane.

$\mathrm{G})$ and $\mathrm{H}$ ) This shows LTA staining in the zebra ( $\mathrm{G}: 239$ days) and horse ( $\mathrm{H}: 280$ days) placentae, with absence of stain in the horse microvillous membrane (MVM), but some degree of binding in the zebra, equivalent. ME: maternal epithelium, T: trophoblast.

I) and J) DBA staining in the zebra placenta at 239 days compared with that of the horse (280 days) shows similar strong staining of the maternal epithelium (ME), though granular in the horse and more diffuse in zebra, but more stained inclusions in the horse trophoblast 


\section{Table 1: Details of the material used in this study.}

\begin{tabular}{|c|c|c|c|}
\hline Species & $\frac{\text { Days of }}{\text { gestation }}$ & $\frac{\text { CR length }}{(\mathrm{cm})}$ & $\begin{array}{l}\text { Weight of } \\
\text { embryo (g) }\end{array}$ \\
\hline Horse & 50 & $\sim 43^{*}$ & N/A \\
\hline Horse & 200 & $\sim 53^{*}$ & $N / A$ \\
\hline Horse & 280 & $\sim 75^{*}$ & $N / A$ \\
\hline Donkey & $\mathrm{N} / \mathrm{A}$ & $65 \mathrm{~cm}$ & $\mathrm{~N} / \mathrm{A}$ \\
\hline Zebra & 81 & 10 & 14.3 \\
\hline Zebra & 117 & 24 & 230 \\
\hline Zebra & 195 & 58 & 2790 \\
\hline Zebra & 230 & 72 & 5580 \\
\hline Zebra & 239 & 72 & 6590 \\
\hline
\end{tabular}

*Estimated from [26] $\quad \mathrm{CR}=$ crown-rump; $\mathrm{N} / \mathrm{A}=$ not available 
Table 2: Lectins used in this study and their major specificities

\begin{tabular}{|c|c|c|}
\hline ACRONYM & SOURCE & MAJOR SPECIFICITY \\
\hline GNA & $\begin{array}{l}\text { Galanthus nivalis } \\
\text { Snowdrop }\end{array}$ & $\begin{array}{l}\text { Nonreducing terminal a-D-mannose, especially the mannosyl } \\
\alpha 1,3 \text { mannose linkage }\end{array}$ \\
\hline CON A & $\begin{array}{l}\text { Canavalia ensiformis } \\
\text { Jackbean }\end{array}$ & $\begin{array}{l}\alpha \text {-D-glucosyl and } \alpha \text {-D-mannosyl (terminal or } 1,2 \text { linked) in high } \\
\text { mannose, intermediate and small complex } \mathrm{N} \text {-linked sequences }\end{array}$ \\
\hline PSA & $\begin{array}{l}\text { Pisum sativum } \\
\text { Garden Pea }\end{array}$ & $\begin{array}{l}\alpha \text {-D-mannose in non-bisected bi/tri-antennary, complex } \mathrm{N} \text { - linked } \\
\text { sequences }\end{array}$ \\
\hline e-PHA & $\begin{array}{l}\text { Phaseolus vulgaris } \\
\text { (erythroagglutinin) } \\
\text { Kidney Bean }\end{array}$ & Bi/tri-antennary bisected complex N-linked sequences \\
\hline I-PHA & $\begin{array}{l}\text { Phaseolus vulgaris } \\
\text { (leukoagglutinin) } \\
\text { Kidney Bean }\end{array}$ & Tri/tetra-antennary, non- bisected complex $\mathrm{N}$-linked sequences \\
\hline UEA-1 & $\begin{array}{l}\text { Ulex europaeus-1 } \\
\text { Gorse }\end{array}$ & $\mathrm{H}$ type 2 antigen ( $\alpha \mathrm{L}-\mathrm{Fuc}(1,2)$ Galß1,4GIcNAcß1-) and Le ${ }^{y}$ \\
\hline LTA & $\begin{array}{l}\text { Tetragonolobus purpureus } \\
\text { Lotus }\end{array}$ & $\begin{array}{l}\text { L-fucosyl terminals (especially where clustered), Fuc } \alpha 1,6 \mathrm{GlcNAc} \\
\text { >Fuc } \alpha 1,2-\text { Galß1,4(Fuc } \alpha 1,3) \text {-GlcNAcß, Le }\end{array}$ \\
\hline ALA & $\begin{array}{l}\text { Aleuria aurantia } \\
\text { Mushroom }\end{array}$ & Fucose linked $\alpha 1,6$ - to GlcNAc \\
\hline DBA & $\begin{array}{l}\text { Dolichos biflorus } \\
\text { Horse Gram }\end{array}$ & GalNAc $\alpha 1,3($ LFuc $\alpha 1,2)$ Galß1,3/4GlcNAcß1- \\
\hline VVA & $\begin{array}{l}\text { Vicia villosa } \\
\text { Hairy vetch }\end{array}$ & GalNAc $\alpha 1-S e r / T h r$ and GalNAc $\alpha 1,3$ Galß1- \\
\hline HPA & $\begin{array}{l}\text { Helix pomatia } \\
\text { Roman snail }\end{array}$ & Terminal GalNAc $\alpha 1-$ \\
\hline WFA & $\begin{array}{l}\text { Wisteria floribunda } \\
\text { Wisteria }\end{array}$ & GalNAc $\alpha 1,6 \mathrm{Gal} ß 1-\quad>$ GalNAc $\alpha 1,3 \mathrm{Gal} ß 1-$ \\
\hline SBA & $\begin{array}{l}\text { Glycine max } \\
\text { Soybean }\end{array}$ & Terminal GalNAc $\alpha 1-$ \\
\hline $\mathrm{AHA}$ & $\begin{array}{l}\text { Arachis hypogaea } \\
\text { Peanut }\end{array}$ & $>$ Galß1,4GlcNAcß1- \\
\hline ECA & $\begin{array}{l}\text { Erythrina cristagalli } \\
\text { Coral Tree }\end{array}$ & Galß1,4GlcNAcß1- \\
\hline MPA & $\begin{array}{l}\text { Maclura pomifera } \\
\text { Osage orange }\end{array}$ & Galß1,3GalNAca1- > GalNAca1- \\
\hline $\mathrm{BSA}-1 \mathrm{~B}_{4}$ & $\begin{array}{l}\text { Bandeiraea simplicifolia } \\
\text { Griffonia }\end{array}$ & Gal 1 1,3Galß1,4GlcNAcß1- \\
\hline DSA & $\begin{array}{l}\text { Datura stramonium } \\
\text { Jimson Weed }\end{array}$ & B1,4GlcNAc, N-Acetyl lactosamine >chitotriose \\
\hline STA & $\begin{array}{l}\text { Solanum tuberosum } \\
\text { Potato }\end{array}$ & B1,4GlcNAc oligomers \\
\hline LEA & $\begin{array}{l}\text { Lycopersicon esculentum } \\
\text { Tomato }\end{array}$ & B1,4GlcNAc oligomers \\
\hline PAA & $\begin{array}{l}\text { Phytolacca Americana } \\
\text { Pokeweed }\end{array}$ & Similar to WGA \\
\hline WGA & $\begin{array}{l}\text { Triticum vulgaris } \\
\text { Wheatgerm }\end{array}$ & $\begin{array}{l}\text { Di-N-acetyl chitobiose, } \mathrm{N} \text {-acetyl lactosamine (especially if } \\
\text { clustered) and some sialyl residues }\end{array}$ \\
\hline SNA & $\begin{array}{l}\text { Sambucus nigra } \\
\text { Elderberry Bark }\end{array}$ & NeuNAc $\alpha 2,6 \mathrm{Gal} / \mathrm{GalNAc-}$ \\
\hline MAA & Maackia amurensis & NeuNAc $\alpha 2,3 G a l ß 1$ - \\
\hline
\end{tabular}


Table 3: Lectin staining of trophoblast in horse, donkey and zebra.

Key: 0: negative,1: weak, 2: moderate. 3: strong, 4: intense. Granule density from sparse (-/+) to dense (+++). G: possible Golgi bodies

\begin{tabular}{|c|c|c|c|c|c|c|c|c|c|c|c|c|c|c|c|c|c|c|}
\hline \multirow[t]{3}{*}{ Lectin } & \multicolumn{6}{|c|}{ Horse } & \multirow{2}{*}{\multicolumn{2}{|c|}{$\begin{array}{l}\text { Donkey } \\
65 \mathrm{~cm}\end{array}$}} & \multicolumn{10}{|c|}{ Zebra } \\
\hline & \multicolumn{2}{|c|}{ 50d $(\sim 43 \mathrm{~cm})$} & \multicolumn{2}{|c|}{ 200d ( 53cm) } & \multicolumn{2}{|c|}{ 280d ( 75cm) } & & & \multicolumn{2}{|c|}{$81 d(10 \mathrm{~cm})$} & \multicolumn{2}{|c|}{$117 d(24 \mathrm{~cm})$} & \multicolumn{2}{|c|}{$195 \mathrm{~d}(58 \mathrm{~cm})$} & \multicolumn{2}{|c|}{$230 \mathrm{~d}(72 \mathrm{~cm})$} & \multicolumn{2}{|c|}{ 239d (72cm) } \\
\hline & Cyt & Gran & Cyt & Gran & Cyt & Gran & Cyt & Gran & Cyt & Gran/ves & Cyt & Gran/ves & Cyt & Gran/ves & Cyt & Gran/ves & Cyt & Gran/ves \\
\hline GNA & $1-2$ & $3-4+++$ & 0 & $3-4++$ & 1 & $3-4+++$ & 1 & $3-4+$ & 3 & 3 & $1-2$ & $2-3$ & $1-2$ & $3+++$ & 2 & $3-4++$ & 2 & $3-4+++$ \\
\hline CONA & 2 & $4+++$ & 2 & $2+++$ & 2 & $3-4++$ & 2 & $3++$ & 3 & $3-4+++$ & $3-4$ & $3-4+++$ & 2 & $2+++$ & $3-4$ & $3-4+++$ & 2 & $2++$ \\
\hline PSA & 1 & $4++$ & 1 & $4+$ & 1 & $4++$ & 1 & $3-4++$ & $2-3$ & $4++$ & 2 & $2-3++$ & $2-3$ & $2-3++$ & $2-3$ & $4++$ & 2 & $3++$ \\
\hline ePHA & 2 & $4++$ & 2 & $2+++$ & 2 & $4++$ & 2 & $3-4+$ & $3-4$ & $4+$ & $2-3$ & $2-3++$ & $2-3$ & $2-3++G$ & 3 & $3++$ & $2-3$ & $2-3++$ \\
\hline $\mathrm{IPHA}$ & 0 & $2++$ & 0 & $3+$ & 1 & $3+$ & 0 & $3-4+$ & $0-1$ & $1-2++$ & 2 & $3-4+$ & $1-2$ & $3++$ & $1-2$ & $1-2+$ & $1-2$ & $1-2++$ \\
\hline LTA & 0 & 0 & 0 & 0 & 0 & 0 & 0 & 0 & 2 & $2+++$ & 2 & $2+++$ & 2 & $2+++$ & 2 & $2++$ & $1-2$ & $1-2+$ \\
\hline UEA-1 & 0 & 0 & 0 & 0 & 0 & 0 & 0 & 0 & 1 & $1++$ & 1 & $1++$ & 1 & $1++$ & 1 & $1++$ & 1 & $1++$ \\
\hline ALA & 2 & $3+++$ & 0 & $3-4++$ & 1 & $3-4++$ & 1 & $3-4++$ & 3 & $3-4++$ & $2-3$ & $2-3++G$ & $2-3$ & $2-3++G$ & $2-3$ & $2-3++G$ & $2-3$ & $2-3++G$ \\
\hline DBA & 0 & $4++$ & 0 & $3+$ & 0 & $4+$ & 0 & $4-/+$ & $1-2$ & $1-2+$ & $1-2$ & $2+$ & $0-1$ & $1+$ & 1 & $1-2+$ & 1 & $1-2+$ \\
\hline VVA & 0 & $3-4++$ & 0 & $3-4+$ & 0 & $3-4+++$ & $0-1$ & $2-3++$ & $2-3$ & $2-3+$ & $1-2$ & $2+$ & $1-2$ & $2+$ & 1 & $1-2+$ & $0-1$ & $1-2+$ \\
\hline MPA & 1 & $3+++$ & 0 & $2-4+++$ & 1 & 3-4+++ & $1-2$ & $3-4++$ & $3-4$ & $3-4++$ & $2-3$ & $2-3+$ & $2-3$ & $3+$ & 2 & $2-3+$ & $2-3$ & $3+$ \\
\hline $\mathrm{BSA}-1_{\mathrm{B} 4}$ & 1 & $3-4++$ & 0 & $3-4+$ & 1 & $3-4+++$ & 1 & $3-4++$ & $2-3$ & $2-3++$ & 2 & $2-3++$ & $1-2$ & $2-3++G$ & 2 & $2-3++G$ & 2 & $2-3++G$ \\
\hline DSA & 1 & $3-4+++$ & 1 & 3-4++++ & 1 & 3-4+++ & $1-2$ & $2-3++$ & 2 & $2-3+++$ & $2-3$ & $3++$ & $2-3$ & $2-3++$ & $2-3$ & $2-3+++$ & 2 & $2-3++$ \\
\hline STA & 2 & $3-4+++$ & $1-2$ & $3-4+++$ & $1-2$ & $3-4+++$ & 2 & $2-3++$ & 3 & $3+++$ & $2-3$ & $3++$ & $2-3$ & $2-3++$ & $2-3$ & $2-3+++$ & $2-3$ & $2-3+$ \\
\hline LEA & 1 & $3-4+++$ & 0 & $3-4++$ & $0-1$ & 3-4+++ & 0 & $3-4++$ & 2 & $2-3+++$ & 2 & $2-3+G$ & 2 & $2-3++$ & $1-2$ & $2-3++G$ & 2 & $3++$ \\
\hline HPA & 0 & $2-3+++$ & $0-1$ & 3-4++ & $0-1$ & $2-3++$ & $0-1$ & $2-3+$ & $2-3$ & $2-3+++$ & $2-3$ & $2-3+++$ & $2-3$ & $2-3+++$ & 2 & $2-3++$ & 2 & $2-3+$ \\
\hline $\mathrm{AHA}$ & 1 & $3-4+++$ & $0-1$ & 3-4++ & $0-1$ & $3-4+++$ & $0-1$ & $3-4++$ & 3 & $3-4++$ & 2 & $2-3++$ & $1-2$ & $2+$ & 2 & $2-3++$ & 2 & $2-3+$ \\
\hline $\mathrm{AHA}+\mathrm{N}$ & 1 & $3-4++$ & 1 & $2-3++$ & 1 & $2=3+++$ & 1 & $2-3+++$ & $2-3$ & $3-4++$ & 2 & $2-3++$ & 2 & $2-3+$ & 2 & $2-3++$ & 1 & $1-2+$ \\
\hline ECA & 1 & $3-4++$ & $0-1$ & $3-4++$ & 1 & 3-4+++ & $0-1$ & $3-4++$ & 2 & $2-3++$ & $1-2$ & $2-3++$ & 1 & $1-2+$ & $1-2$ & $2-3+$ & 1 & $1-2+$ \\
\hline $\mathrm{ECA}+\mathrm{N}$ & 0 & $2-3+$ & $0-1$ & $3-4++$ & $0-1$ & $2-3+++$ & $0-1$ & $2-3++$ & $1-2$ & $2-3++$ & $1-2$ & $2++$ & 1 & $1-2+$ & $1-2$ & $2-3+$ & 1 & $1-2+$ \\
\hline SBA & 1 & $3-4++$ & 0 & $2-3++$ & $0-1$ & $2-3++$ & 0 & $2+$ & $1-2$ & $2-3++$ & $1-2$ & $2-3++$ & $1-2$ & $2+$ & 1 & $1-2++$ & $1-2$ & $2+$ \\
\hline $\mathrm{SBA}+\mathrm{N}$ & 0 & $3-4++$ & $0-1$ & $2-3++$ & $0-1$ & $2+++$ & 0 & $2+$ & $1-2$ & $2-3+$ & $1-2$ & $2++$ & 1 & $1-2+/-$ & 1 & $1-2++$ & 1 & $1-2+$ \\
\hline WFA & 2 & $3-4+++$ & 1 & $3-4+++$ & $0-1$ & $3-4++$ & 1 & $3-4++$ & $2-3$ & $3-4++$ & $2-3$ & $3++$ & 2 & $2-3+$ & 2 & $2-3++$ & 2 & $2-3++$ \\
\hline SNA-1 & $0-1$ & $2-3++$ & $0-1$ & $2+$ & 0 & 0 & $0-1$ & $1-2+$ & 3 & $3-4++$ & $2-3$ & $2-3+++$ & 3 & $3+++$ & $2-3$ & $2-3+++$ & 3 & $3+++$ \\
\hline SNA-1+N & $0-1$ & $2++$ & 0 & 0 & 0 & 0 & 0 & 0 & 2 & $3++$ & 1 & $2-3+$ & 3 & $3+++$ & 2 & $2+++$ & 3 & $3+++$ \\
\hline MAA & 0 & 0 & 0 & 0 & 0 & 0 & 0 & 0 & $0-1$ & $1-2++$ & 1 & $1-2+$ & 1 & $1+++$ & $0-1$ & $1+++$ & 1 & $1+++$ \\
\hline $\mathrm{MAA}+\mathrm{N}$ & 0 & 0 & 0 & 0 & 0 & 0 & 0 & 0 & 0 & $0-1+$ & $0-1$ & $0-1+$ & $0-1$ & $0-1$ & $0-1+++$ & $0-1+++$ & 0 & $0-1+++$ \\
\hline PAA & 1 & $3-4+++$ & $0-1$ & $2-4++$ & 1 & $2-4++$ & $0-1$ & $3-4+$ & 3 & $3-4++$ & 2 & $2-3++$ & 2 & $2-3++G$ & 2 & $2-3++G$ & 2 & $2-3+G$ \\
\hline $\mathrm{PAA}+\mathrm{N}$ & 1 & $3-4+++$ & $0-1$ & $2-4++$ & 1 & $2-3++$ & 0 & $3+$ & 3 & $3-4++$ & 2 & $2++$ & 2 & $2-3++G$ & 2 & $2-3++G$ & $1-2$ & $2-3+G$ \\
\hline WGA & 1 & $3-4++$ & 1 & $3-4++$ & 1 & $3-4++$ & $0-1$ & $3+$ & 3 & $3-4++$ & 2 & $2-3++$ & $1-2$ & $3-4+G$ & $1-2$ & $2-3+G$ & $1-2$ & $2-3+G$ \\
\hline WGA+N & 1 & $3-4+++$ & $0-1$ & $3-4+$ & $0-1$ & $3-4++$ & 1 & $3+$ & 3 & $3-4++$ & 2 & $2-3++$ & $1-2$ & $3-4+G$ & $1-2$ & $2++G$ & 1 & $2++G$ \\
\hline
\end{tabular}


Table 4: Lectin staining of maternal uterine epithelium in horse, donkey and zebra

Key: 0: negative,1: weak, 2: moderate. 3: strong, 4: intense. Granule density from sparse (-/+) to dense (+++). G: possible Golgi bodies

\begin{tabular}{|c|c|c|c|c|c|c|c|c|c|c|c|c|c|c|c|c|c|c|}
\hline \multirow[t]{3}{*}{ Lectin } & \multicolumn{6}{|c|}{ Horse } & \multirow{2}{*}{\multicolumn{2}{|c|}{$\begin{array}{l}\text { Donkey } \\
65 \mathrm{~cm}\end{array}$}} & \multicolumn{10}{|c|}{ Zebra } \\
\hline & \multicolumn{2}{|c|}{ 50d ( 43cm) } & \multicolumn{2}{|c|}{$200 \mathrm{~d}(\sim 53 \mathrm{~cm})$} & \multicolumn{2}{|c|}{$280 \mathrm{~d}(\sim 75 \mathrm{~cm})$} & & & \multicolumn{2}{|c|}{$81 d(10 \mathrm{~cm})$} & \multicolumn{2}{|c|}{$117 d(24 \mathrm{~cm})$} & \multicolumn{2}{|c|}{$195 d(58 \mathrm{~cm})$} & \multicolumn{2}{|c|}{$230 \mathrm{~d}(72 \mathrm{~cm})$} & \multicolumn{2}{|c|}{ 239d (72cm) } \\
\hline & Cyt & Gran & Cyt & Gran & Cyt & Gran & Cyt & Gran & Cyt & Gran/ves & Cyt & Gran/ves & Cyt & Gran/ves & Cyt & Gran/ves & Cyt & Gran/ves \\
\hline GNA & 1 & $2-/+$ & 1 & $4++$ & 1 & $4++$ & 1 & $3-4++$ & 1 & $3-4++$ & 1 & $1-2++$ & $1-2$ & $3-4++$ & 2 & $3-4++$ & 2 & $3-4++$ \\
\hline CONA & 2 & $3+/-$ & 2 & $4-/+$ & 2 & $4-/+$ & 2 & $3-4+$ & $3-4$ & $3-4+++$ & $3-4$ & $3-4+++$ & 2 & $2++$ & $3-4$ & $3-4++$ & 2 & $2+$ \\
\hline PSA & 1 & $3+/-$ & 1 & $4+$ & 1 & $4+$ & 1 & $3-4+$ & $2-3$ & $3+$ & 2 & $2++$ & 2 & $2-3+$ & 2 & $2+$ & 2 & $2+$ \\
\hline ePHA & 1 & $3+$ & 2 & $4+$ & 2 & $4+$ & 2 & $3-4+$ & $3-4$ & $4++G$ & 2 & $2-3++G$ & 2 & $2-3+G$ & 2 & $3+G$ & 2 & $3++G$ \\
\hline IPHA & 0 & 0 & 0 & $2+$ & 0 & $2+$ & 0 & 0 & 0 & $0-1+$ & 1 & $1-2+$ & 1 & $1++$ & 1 & $1-2+$ & 1 & $1++$ \\
\hline LTA & 0 & 0 & 0 & 0 & 0 & 0 & 0 & 0 & 2 & $2+++$ & 2 & $2+++$ & 2 & $2++$ & 2 & $2++$ & 1 & $1+$ \\
\hline UEA-1 & 1 & $2-3+$ & 2 & $3-4++$ & 2 & $3-4++$ & 0 & $4++$ & 3 & $3-4+++$ & 2 & $2-3++$ & $2-3$ & $2-3++$ & $2-3$ & $2-3++$ & $2-3$ & $2-3++$ \\
\hline ALA & 2 & 2 & $1-2$ & $3-4++$ & $1-2$ & $3-4++$ & 1 & $3-4+$ & 3 & $3-4++$ & $2-3$ & $2-3++$ & $2-3$ & $2-3++$ & $2-3$ & $2-3++G$ & $2-3$ & $2-3++$ \\
\hline DBA & 0 & $3++$ & 2 & 3-4+++ & 2 & 3-4+++ & 1 & $3-4++$ & $2-3$ & $3-4++G$ & 3 & $3-4+G$ & $2-3$ & $3-4+G$ & $2-3$ & $2-3+G$ & 3 & $3-4+G$ \\
\hline VVA & 0 & $3++$ & 1 & $3-4+++$ & 1 & $3-4+++$ & 1 & $3-4++$ & $2-3$ & $3-4+G$ & $2-3$ & $3-4+G$ & $2-3$ & $3+G$ & $2-3$ & $3+g$ & $2-3$ & $3-4+G$ \\
\hline MPA & 0 & $2+$ & 1 & $3-4++$ & 1 & $3-4++$ & 2 & $3-4++$ & $2-3$ & $34+$ & $1-2$ & $2-3+$ & $2-3$ & $3+$ & 2 & $2-3+$ & 2 & $2-3+$ \\
\hline BSA-1 ${ }_{B 4}$ & 0 & $2-/+$ & 0 & 0 & 0 & 0 & 0 & 0 & 2 & $2-3++$ & 1 & $1-2++$ & 1 & $1-2+$ & 0 & $1-2+$ & 0 & $0-1+$ \\
\hline DSA & 1 & $2++$ & 0 & $3-4++$ & 0 & $3-4++$ & $1-2$ & $3-4++$ & 3 & $3+++$ & $2-3$ & $3++$ & 2 & $2-3+$ & 2 & $2-3+$ & 2 & $2-3+$ \\
\hline LEA & 0 & $2+$ & $0-1$ & $3-4++$ & $0-1$ & $3-4++$ & $0-1$ & $3-4++$ & 3 & $3+++$ & 2 & $2-3+$ & 2 & $2-3++$ & $1-2$ & $2-3+$ & $2-3$ & $2-3++$ \\
\hline HPA & 1 & $3+$ & $0-1$ & $3-4++$ & $0-1$ & $3-4++$ & $0-1$ & $3-4++$ & 3 & $3+++$ & $2-3$ & $2-3++$ & $2-3$ & $2-3++$ & 2 & $2-3+$ & 2 & $2-3+$ \\
\hline $\mathrm{AHA}$ & 0 & $3++$ & 1 & $3-4+++$ & 1 & $3-4+++$ & 0 & $3-4++$ & 2 & $3-4++$ & 2 & $2-3++$ & $1-2$ & $2+$ & $1-2$ & $2+$ & $1-2$ & $2-3+$ \\
\hline $\mathrm{AHA}+\mathrm{N}$ & 0 & $2+$ & 1 & 3-4+++ & 1 & $3-4+++$ & 0 & $3-4++$ & 2 & $3-4++$ & $1-2$ & $2-3++$ & 2 & $2-3+$ & 2 & $2+$ & 1 & $1-2+/-$ \\
\hline ECA & 1 & $3++$ & $0-1$ & 3-4+++ & $0-1$ & $3-4+++$ & $0-1$ & $3-4++$ & $2-3$ & $3-4++$ & $1-2$ & $2-3++$ & $0-1$ & $1-2+$ & 2 & $2-3+$ & 1 & $1-2+$ \\
\hline $\mathrm{ECA}+\mathrm{N}$ & 0 & $2+$ & $0-1$ & $3-4+++$ & $0-1$ & $3-4+++$ & $0-1$ & $3-4++$ & $2-3$ & $3++$ & $1-2$ & $2++$ & $1-2$ & $2-3+$ & 2 & $2-3+$ & 1 & $1-2+$ \\
\hline SBA & 1 & $3++$ & $0-1$ & $3-4+++$ & $0-1$ & $3-4+++$ & 0 & $3-4++$ & $2-3$ & $3++$ & $2-3$ & $2-3++$ & 2 & $2-3+$ & $1-2$ & $2+$ & 2 & $2-3++$ \\
\hline $\mathrm{SBA}+\mathrm{N}$ & 0 & $3++$ & $0-1$ & 3-4+++ & $0-1$ & 3-4+++ & 0 & $3-4++$ & 3 & $3-4+++$ & 2 & $2-3++$ & $1-2$ & $2-3+$ & $1-2$ & $2+$ & $1-2$ & $2++$ \\
\hline WFA & 2 & $2+++$ & 2 & 3-4+++ & 2 & 3-4+++ & $1-2$ & $3-4++$ & 4 & $4+++$ & 3-4 & $4++$ & 3 & $3-4++G$ & $2-3$ & $2-3+G$ & 3 & $3-4++G$ \\
\hline SNA-1 & $0-1$ & $2++$ & 1 & $2-3++$ & 1 & $2-3++$ & $0-1$ & $2+$ & 3 & $3-4++$ & $2-3$ & $2-3++$ & 3 & $3+++$ & 2 & $2+++$ & 3 & $3+++$ \\
\hline SNA-1+N & $0-1$ & $2+$ & 0 & 0 & 0 & 0 & 0 & 0 & $2-3$ & $3-4++$ & 1 & $2+$ & 3 & $3+++$ & 2 & $2+++$ & 3 & $3+++$ \\
\hline MAA & 0 & 0 & 0 & 0 & 0 & $3-/+$ & 0 & 0 & 0 & $1+$ & 1 & $1-2+$ & 1 & $1-2++$ & 0 & $1++$ & 1 & $1+++$ \\
\hline $\mathrm{MAA}+\mathrm{N}$ & 0 & 0 & 0 & 0 & 0 & 0 & 0 & 0 & 0 & 0 & 0 & $0-1+$ & $0-1$ & $0-1+$ & 0 & $0++$ & 0 & $0-1+++$ \\
\hline PAA & $0-1$ & $2-3++$ & 1 & 3-4+++ & 1 & 3-4+++ & $0-1$ & $3-4++$ & $3-4$ & $4++$ & 1 & $2++$ & 1 & $2-3+G$ & $1-2$ & $2+G$ & $1-2$ & $2-3+G$ \\
\hline $\mathrm{PAA}+\mathrm{N}$ & $0-1$ & $2+$ & 1 & 3-4+++ & 1 & 3-4+++ & 0 & $3-4+$ & $3-4$ & $4++$ & $1-2$ & $2-3+$ & $1-2$ & $2-3+G$ & $1-2$ & $2+G$ & $1-2$ & $2-3+G$ \\
\hline WGA & $0-1$ & $2-3++$ & 1 & $3-4++$ & 1 & $3-4++$ & $0-1$ & $3-4++$ & 3 & $4++$ & 2 & $2-3++$ & $1-2$ & $3+G$ & $1-2$ & $2-3+G$ & $1-2$ & $2-3+G$ \\
\hline
\end{tabular}




\section{Figure}

Click here to download Figure: Zebra Figure 1.pptx
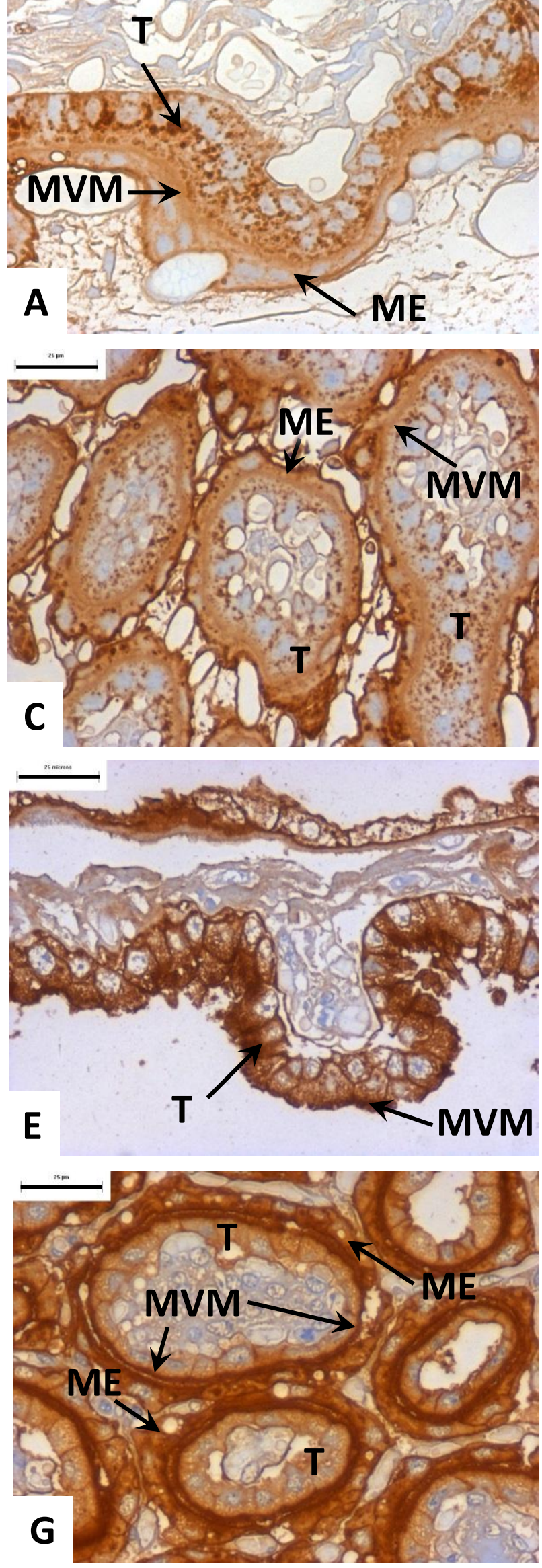
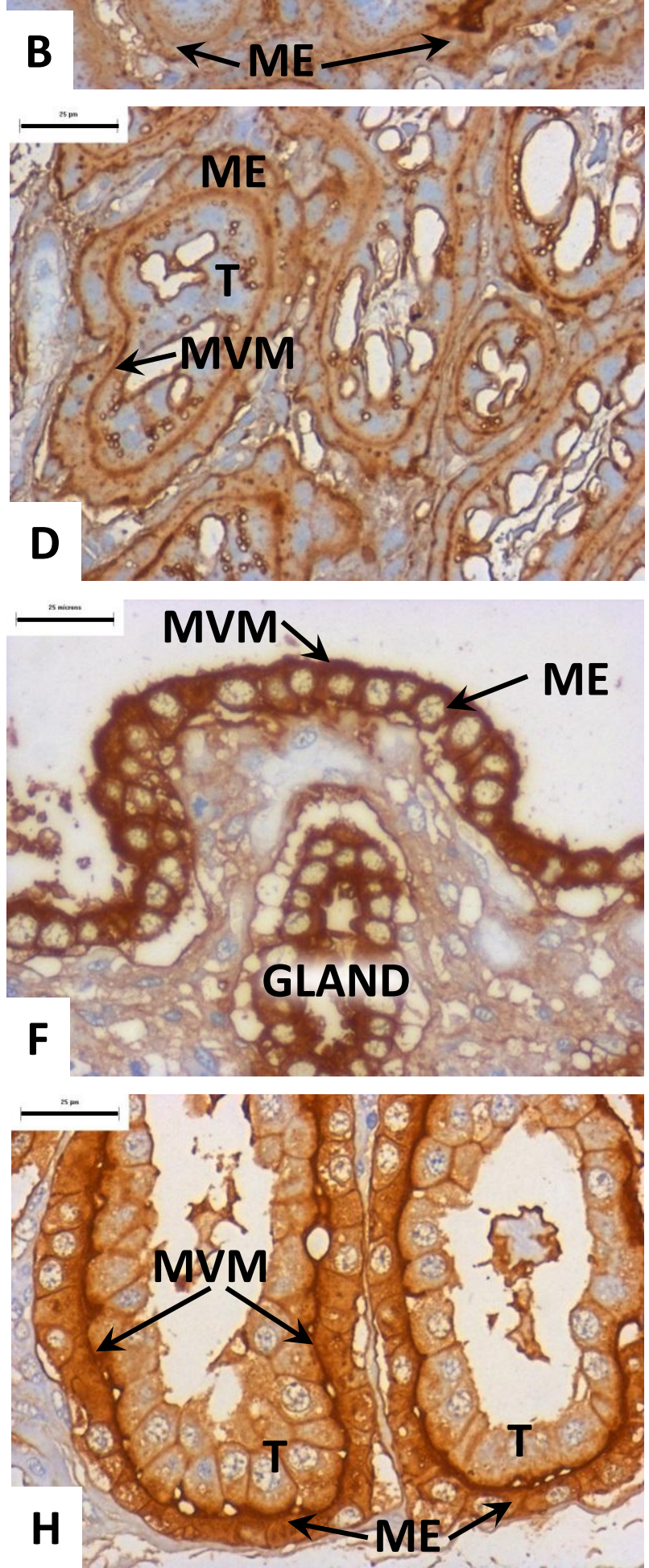
Figure
Click here to download Figure: Revised Figure zppte
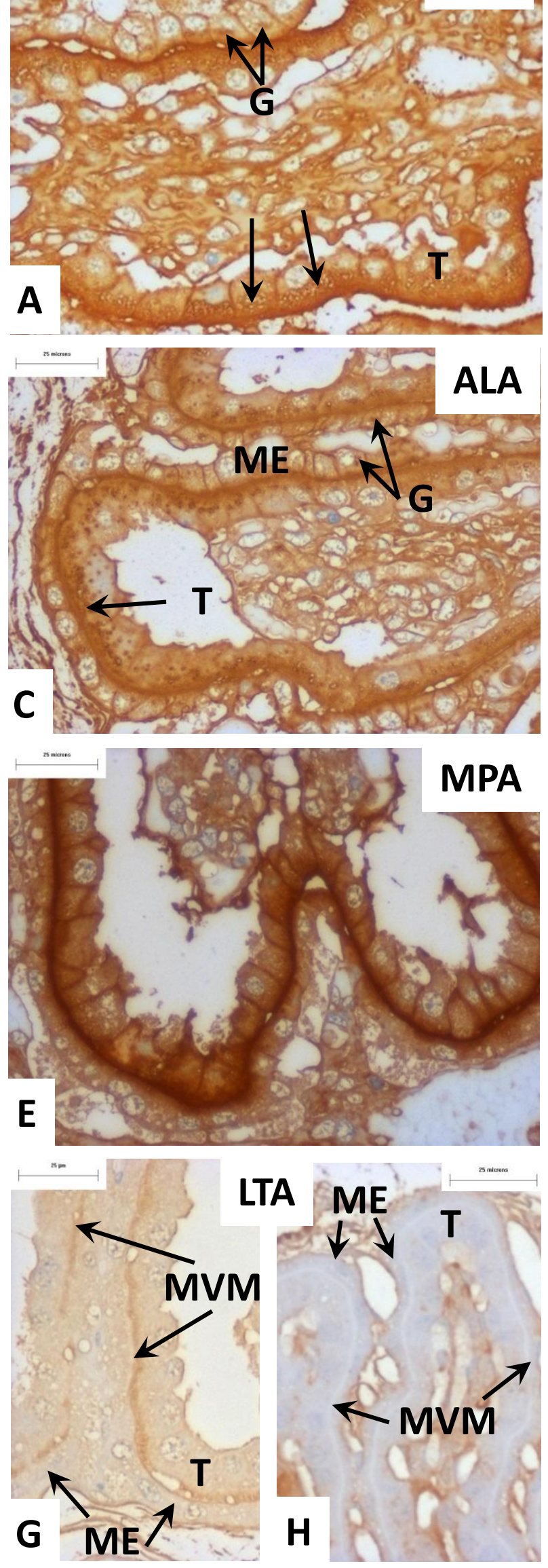

$\operatorname{G}_{\mathrm{ME}} \lambda^{\mathrm{T}}$

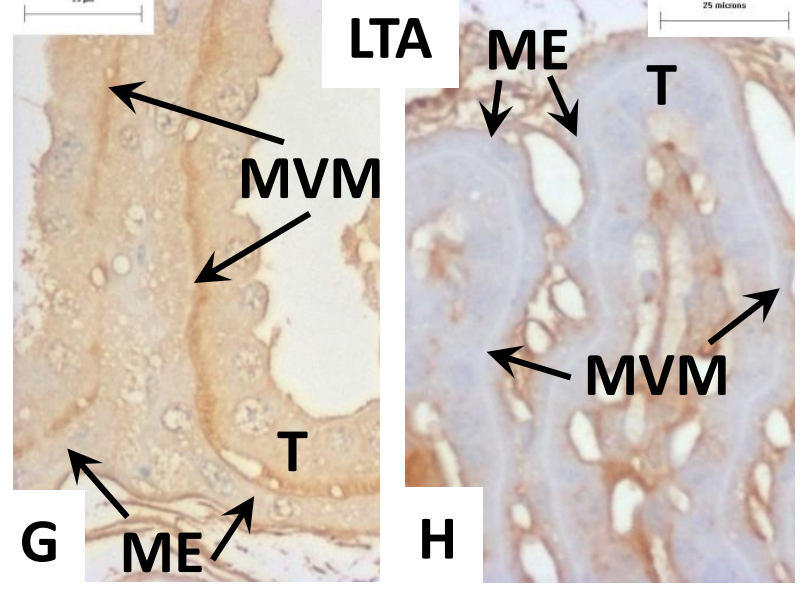

F
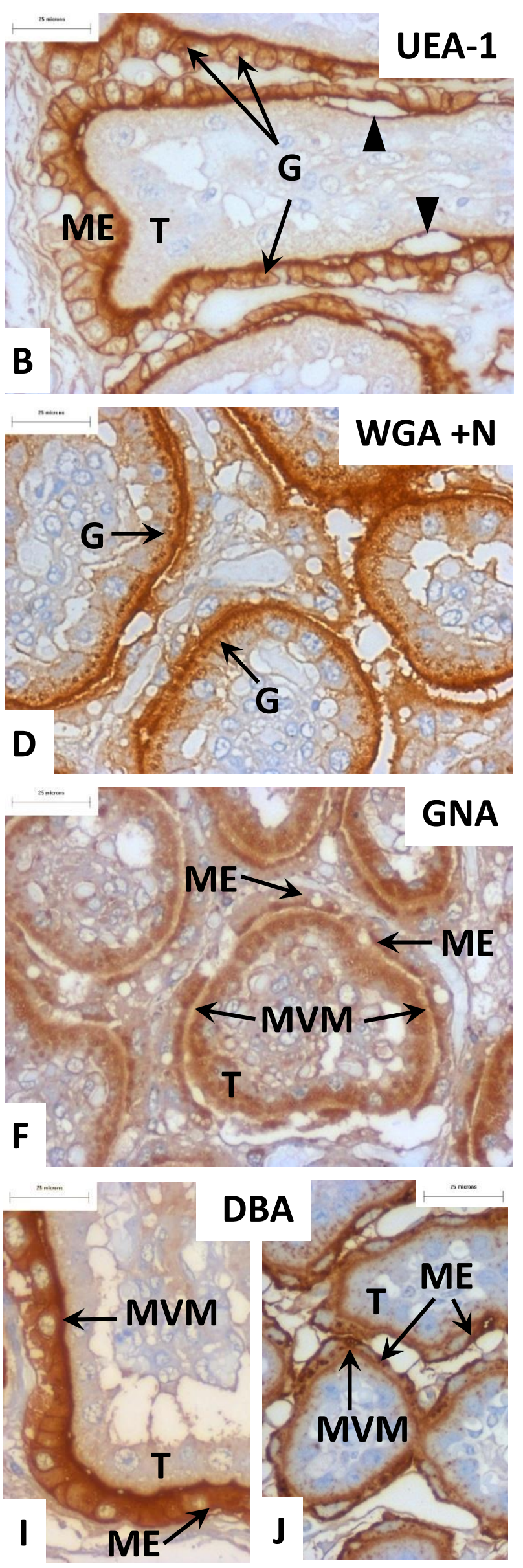

\section{DBA}

